\title{
Erratum to: Characterization of micrometer-sized magnetic optical sensor particles produced via spray-drying
}

\author{
Klaus Koren • Günter Mistlberger · Daniel Aigner • \\ Sergey M. Borisov • Armin Zankel · Peter Pölt • \\ Ingo Klimant
}

Published online: 11 March 2010

(C) Springer-Verlag 2010

\section{Erratum to: Monatsh Chem}

\section{DOI 10.1007/s00706-010-0262-z}

Due to a processing error, the presentation of Table 1 was incorrect. The correct Table 1 is given below.

Table 1 Applicability of polymers with varying maleic anhydride (MA) content and molecular weight (MW) for spray-drying

\begin{tabular}{lcclll}
\hline Polymer & $\begin{array}{l}\text { MA } \\
(\mathrm{wt} \%)\end{array}$ & $\begin{array}{l}\text { MW } \\
\left(\mathrm{g} \mathrm{mol}^{-1}\right)\end{array}$ & $\begin{array}{l}\text { Suitability for } \\
\text { spray-drying }\end{array}$ & $\begin{array}{l}\text { Sensor } \\
\text { performance }\end{array}$ & $\begin{array}{l}K_{\mathrm{SV}} \\
\left(\mathrm{hPa}^{-1}\right)\end{array}$ \\
\hline PSMA93 & 7 & 224,000 & + & ++ & 0.00181 \\
EF 80 & 11.11 & 14,400 & + & + & 0.00135 \\
EF 60 & 14.29 & 11,500 & + & - & NA \\
PSMA75 & 25 & 1,900 & - & -- & NA \\
PS & 0 & 220,000 & NA & NA & 0.0042 \\
\hline
\end{tabular}

The online version of the original article can be found under doi:10.1007/s00706-010-0262-z.

K. Koren · G. Mistlberger $(\bowtie) \cdot D$. Aigner ·

S. M. Borisov · I. Klimant

Institute of Analytical Chemistry and Food Chemistry,

Graz University of Technology, Graz, Austria

e-mail: mistlberger@tugraz.at

A. Zankel · P. Pölt

Austrian Centre for Electron Microscopy and Nanoanalysis, Institute for Electron Microscopy,

Graz University of Technology, Graz, Austria 